\title{
Should I believe all the truths?
}

\author{
Alexander Greenberg ${ }^{1}$ \\ Received: 31 August 2017 / Accepted: 16 July 2018 / Published online: 24 July 2018 \\ (c) The Author(s) 2018
}

\begin{abstract}
Should I believe something if and only if it's true? Many philosophers have objected to this kind of truth norm, on the grounds that it's not the case that one ought to believe all the truths. For example, some truths are too complex to believe; others are too trivial to be worth believing. Philosophers who defend truth norms often respond to this problem by reformulating truth norms in ways that do not entail that one ought to believe all the truths. Many of these attempts at reformulation, I'll argue, have been missteps. A number of these different reformulations are incapable of carrying out a central role a truth norm is meant to play, that of explaining justification. The truth norm I'll defend, however, avoids the implausible results of a prescription to believe all the truths, but doesn't thereby fail to explain justification. This norm, introduced (but not defended) by Conor McHugh, states that if one has some doxastic attitude about $\mathrm{p}$-i.e. if one believes, disbelieves, or suspends judgement about whether $\mathrm{p}$ - then one ought to believe that $\mathrm{p}$ if and only if $\mathrm{p}$ is true.
\end{abstract}

Keywords Belief · Truth norms · Epistemic justification

\section{The believing-all-the-truths problem}

Consider the following formulation of a truth norm:

OUGHT: One ought to believe that $\mathrm{p}$ if and only if $\mathrm{p}$ is true. ${ }^{1}$

\footnotetext{
${ }^{1}$ I use small caps to indicate the names of norms or principles. I use names rather than numbers to avoid excessive chisholming. "chisholm, v. To make repeated small alterations in a definition or example. 'He started with definition (d.8) and kept chisholming away at it until he ended up with (d.8"',"'”)"' (Dennett and Steglich-Petersen 2008).
}

For helpful comments on previous drafts, I'm grateful to Lucy Campbell, Christopher Cowie, Tim Crane, Arif Ahmed, Bernard Salow, David Jenkins, Matthew Soteriou, and Maria Alvarez, as well as to three anonymous reviewers for Synthese.

\footnotetext{
$\triangle \quad$ Alexander Greenberg

alexander.greenberg@1mh.ox.ac.uk

1 Lady Margaret Hall, University of Oxford, Oxford, UK
} 
Because it is biconditional in form, OUGHT entails that one ought to believe all the truths. Many have claimed that this means we should reject it, for three main reasons.

Firstly, an obligation to believe all the truths violates 'OUGHT' IMPLIES 'CAN':

'OUGHT' IMPLIES 'CAN': If one ought to $\varphi$, then it is possible for one to $\varphi$.

It's not possible to believe all the truths. And, as Krister Bykvist and Anandi Hattiangadi have pointed out, there are truths that are too complex to grasp, let alone believe, such as the conjunction of all the truths (2007, p. 279). And since 'ought' implies 'can', it cannot be the case that one ought to believe all the truths. And so, it is concluded, OUGHT is clearly false (cf. Boghossian 2003, p. 37; Engel 2004, p. 82).

Secondly, some propositions can be true, but can't be truly believed, such as the following proposition:

It is raining and nobody believes that it is raining.

When it is true, OUGHT implies that one ought to believe it. However, if I believe it, then it's not true.

Following Roy Sorensen (1988), Bykvist and Hattiangadi call these propositions 'blindspots' (2007, p. 281). They argue that we should reject any norm which prescribes beliving true blindspots. This is because, they claim, the obligation to believe true blindspots is an obligation one cannot satisfy. As soon as one believes a blindspot, it's then no longer the case that one ought to do so. Bykvist and Hattiangadi claim that we should reject a norm that entails these kinds of unsatisfiable obligations, because of the following principle:

'OUGHT' IMPLIES 'CAN SATISFY': If one ought to $\varphi$, then it is possible for one to $\varphi$ while being obligated to $\varphi$.

Bykvist and Hattiangadi claim that this principle is just as plausible as 'OUGHT' IMPLIES 'CAN': "Just as one cannot be obligated to do the impossible, one cannot be obligated to satisfy requirements that are impossible to satisfy" (2007, p. 282). Since true blindspots show that OUGHT violates 'OUGHT' IMPLIES 'CAN SATISFY', Bykvist and Hattiangadi conclude that OUGHT is false.

Thirdly, the fact that OUGHT prescribes believing all the truths seems problematic because some truths are trivial truths, such as, to use Daniel Whiting's example, "all the truths about the length and colour of each hair on David Cameron's left arm" (2012, p. 283). It doesn't seem we ought to believe such trivial truths, and so, it is concluded again, OUGHT is clearly false.

It's plausible, therefore, that OUGHT should be rejected because it prescribes believing these three problematic kinds of truths: ungraspably complex truths, true blindspots, and trivial truths. In fact, most of those who defend truth norms defend formulations other than OUGHT in order to avoid one or more of these problematic prescriptions (Boghossian 2003, p. 37; Engel 2004, p. 82; Whiting 2010, p. 216; McHugh 2012, 2014; Wedgwood 2013; Raleigh 2013).

I call the task of coming up with a defensible formulation of a truth norm which does not prescribe believing any of these three problematic kinds of truths 'the believing-allthe-truths problem'. While these three different kinds of truths raise distinct problems for OUGHT, it is helpful to have a general name for this set of problems. And these 
three problematic kinds of truths are often discussed together, because they all stem from a prescription to believe all the truths.

In this paper, I argue that most reformulated truth norms put forward in response to the believing-all-the-truths problem are inadequate. In particular, they are incapable of carrying out a central role a truth norm is meant to play, that of explaining justification.

In order to show this, I'll first need to briefly outline how a truth norm is supposed to explain justification. I'll illustrate with reference to OUGHT, but the same structure of explanation applies to other formulations of truth norms.

The core of this explanation is a means-end claim: having justified beliefs is the best means to the end of conforming to a truth norm like OUGHT. To fully understand this means-end claim, we need to note that OUGHT is not the kind of norm one can follow directly. This is because it's what is often called an 'objective' norm, that is, a norm for which it's not transparent to me whether I'm in accordance with it (Boghossian 2003, pp. 38-39, 2005, pp. 211-212). Conformity with OUGHT isn't transparent because we're not omniscient; we can't 'just tell' whether or not our beliefs are true or compare what we believe with what's true.

Given that conformity with OUGHT isn't transparent, believers need to take indirect means to try to conform to it. This will involve following 'subjective' epistemic norms-i.e. norms which one can follow directly-as a means of conforming to OUGHT. And which subjective norms should one follow? According to this kind of explanation, one should follow the norms which, from one's non-omniscient position, look like the best means of conforming to OUGHT. These are claimed to include logical and evidential norms such as the following:

CONSISTENCY: One's beliefs ought to be consistent.

EVIDENCE: One's beliefs ought to be based on evidence.

These subjective norms won't, admittedly, be infallible means of conforming to OUGHT. For example, they might lead to the occasional false but evidentially supported belief. But nevertheless following these subjective norms is supposed to be, according to this explanation, the best means of conforming to OUGHT available to non-omniscient believers like ourselves.

Because it explains other epistemic norms, OUGHT-or whatever formulation of a truth norm is defended-is claimed to be the fundamental norm on belief. It is claimed that belief is subject to evidence and consistency norms because belief is subject to that truth norm. And this explanation of justification in terms of the truth norm is defended on the grounds that beliefs in accordance with these subsidiary evidence and consistency norms just are beliefs that we pre-theoretically take to be justified.

We can summarise this explanation in a slogan: having justified beliefs is the best means of conforming to a truth norm. ${ }^{2}$ This is meant to be an unpacking of the common-sense idea that the point of having a justified belief is to have a true one.

\footnotetext{
${ }^{2}$ As I've stated it, a truth norm explains 'doxastic' justification, what it is to have a justified belief that $p$, rather than 'propositional' justification, what it is to have justification to believe that $p$ (on the distinction, see Turri 2010). This is because in the explanation outlined here, a truth norm explains what it is to have the right response to the evidence. One is doxastically justified if one has the attitude which is the best means of conforming to the truth norm and one is doxastically unjustified if one fails to have the attitude which is the best means of conforming to the truth norm.
} 
Almost everyone who defends a truth norm claims it explains justification in more or less this way (Wedgwood 2002, p. 276; Boghossian 2003, pp. 38-39, 2005, pp. 211-212; Shah 2003, p. 471; Shah and Velleman 2005, p. 520; Engel 2004, p. 82, 2013, p. 207; Millar 2004, pp. 43-47; Whiting 2010, pp. 220-222; McHugh 2012, p. 9, 2014, pp. 167-168; Raleigh 2013, pp. 256-257). This includes all of those who defend reformulated truth norms which they claim avoid the believing-all-the-truths problem. However, I've been specific that the subjective norms one should follow are those which look like the best means of conforming to the objective truth norm in question. Others instead claim that subjective epistemic norms are a good means of trying to conform to the truth norm (McHugh 2012, p. 9), the rational means (Wedgwood 2002, pp. 272-279; Raleigh 2013, p. 256), or the only means one can take (Boghossian 2005, p. 211; Millar 2004, p. 44; Engel 2013, p. 207). I've been specific because my aim is to assess whether competing truth norms generate plausible subjective norms, and this is easiest if I assume that justified beliefs are what look like the best means of conforming to the truth norm. However, as I discuss briefly in the next section, this could be weakened to justified beliefs being a good means of conforming to the truth norm without undermining my argument.

I'll be arguing that most truth norms reformulated in response to the believing-allthe-truths problem are incapable of explaining justification. This is because, as I'll show in Sects. 2 and 3, their formulation also means that the best means of following them does not involve having beliefs which we pre-theoretically take to be justified. Therefore, insofar as a truth norm is supposed to explain justification, these formulations are inadequate. I'll then argue, In Sect. 4, that there is one reformulated truth norm, which does not entail that one ought to believe all the truths, but is still capable of explaining justification. This truth norm states that one ought to believe all and only the truths one has some doxastic attitude about. This norm was originally discussed (but not defended) by Conor McHugh, though I give my own defence of this truth norm and an account of justification in which it features. ${ }^{3}$

\footnotetext{
${ }^{3}$ I'll focus exclusively on truth norms. However, because they centre on the logical form of the norms in question, my arguments could also be applied other norms purporting to explain epistemic statuses like justification and rationality. For example, my arguments in the next section apply equally to the following knowledge norm:
}

KNOWLEDGE: One ought to believe that p only if one knows that $\mathrm{p}$ (Sutton 2005, Sect. 4.1; Littlejohn 2013, p. 310; Williamson Forthcoming, p. 18).

This knowledge norm is purely permissive, because it doesn't positively prescribe believing anything. This means that it can't be the fundamental epistemic norm for the same reasons given the next section in relation to permissive truth norms. More generally, while knowledge norms don't face the same issues as truth norms, most of the points I make can be made mutatis mutandis in relation to knowledge norms. It should be noted that Williamson, who began this 'knowledge first' approach, doesn't claim KNOWLEDGE is the sole fundamental epistemic norm. In response to issues similar to those discussed in the next section, he says "[t]here may be positive norms for knowledge ... and so positive as well as negative norms for beliefs" (Williamson Forthcoming, p. 13). 


\section{Against permissive truth norms}

A first way of reformulating a truth norm is by making it permissive, i.e. so that it doesn't prescribe believing all the truths, it just prescribes believing only truths, or prohibits believing falsehoods. The following are examples:

ONLY IF: One ought to believe that p only if p is true. (Boghossian 2003, p. 37;

Engel 2004, p. 82)

MAY: One may believe that $p$ if and only if $p$ is true. (Whiting 2010, p. 216)

OUGHT NOT: One ought not to believe that $\mathrm{p}$ if and only if $\mathrm{p}$ is false. (Raleigh

2013, p. 249)

These permissive truth norms don't entail that one ought to believe all the truths, and nor do they prescribe believing the three problematic kinds of truths we discussed above: ungraspably complex truths, trivial truths, or true blindpots.

However, the problem with these permissive truth norms is that they don't entail that one ought to believe anything (cf. Bykvist and Hattiangadi 2007, p. 280). Therefore, the best way of ensuring conformity with these norms is to suspend judgement about everything, to adopt the pyrrhonian sceptical stance of epoche. This is because suspending judgement about whether $\mathrm{p}$ guarantees conformity with a permissive truth norm; believing that $\mathrm{p}$, on the other hand, even if one has overwhelming evidence in support of $\mathrm{p}$, is needlessly risky from the point of view of conforming with a permissive truth norm. This means that a permissive truth norm cannot explain justification, because we wouldn't pre-theoretically take someone who suspended judgement about everything to be justified in doing so (cf. McHugh 2012, p. 18).

One may respond that this does not show that a permissive truth norm cannot explain justification; it just shows that a permissive truth norm cannot explain justification by itself. It may explain justification together with other norms that do positively prescribe some beliefs.

I grant that I haven't ruled out a permissive truth norm from playing some role in explaining justification. But that's not what I was trying to do. Defenders of a permissive truth norm typically claim that it is the fundamental norm on belief (see, e.g. Boghossian 2003, pp. 38-39, 2005, pp. 211-212; Engel 2004, p. 82; Whiting 2010, pp. 220-222; Raleigh 2013, pp. 256-257). I am saying this claim is unsustainable, because the best means of conforming to a permissive truth norm is to suspend judgement about everything.

A second response is given by Whiting. He argues that a truth norm being permissive doesn't stop it from explaining justification because, he claims, we should also think of subjective epistemic norms as permissive (2013, pp. 129-131). In other words, in order to follow a permissive truth norm one should follow a permissive evidential norm, such as:

PERMISSIVE EVIDENCE: One may believe that $\mathrm{p}$ if and only if one has sufficient evidence that $\mathrm{p}$.

This evidential norm is also permissive because it does not state that if one has sufficient evidence that $\mathrm{p}$, one ought to believe that $\mathrm{p}$. Whiting defends permissive evidential norms like this one because, he claims, there are infinitely many trivial propositions 
for which I have sufficient evidence. These infinite trivial propositions can be illustrated, Whiting claims, if we think about the logical consequences of propositions we do have sufficient evidence about. For example, if I have sufficient evidence that London is in England, then I also have sufficient evidence that London is in England or Tolstoy wrote Great Expectations, and infinitely many other propositions (Whiting 2013, p. 130). Being epistemically justified, Whiting claims, does not demand believing these propositions, so we should think of evidential norms on belief as permissive (2013, p. 130; cf. Nelson 2010; Littlejohn 2012, pp. 46-47).

This response does not deal with the problem I've raised. Firstly, a permissive truth norm like MAY cannot in fact explain why belief is subject to even a permissive evidential norm like PERMISSIVE EVIDENCE. This is because, as I outlined earlier, a truth norm is supposed to explain why belief is subject to subsidiary norms, such as evidence and consistency norms, because conforming to those subsidiary norms, it is claimed, is the best means of ensuring conformity to a permissive truth norm. The problem for Whiting is that PERMISSIVE EVIDENCE is not the best means of ensuring conformity with MAY. The best means of ensuring that one does not violate MAY is to suspend judgement about everything. Believing that $\mathrm{p}$ when one has sufficient evidence does not guarantee conformity with MAY (given the plausible fallibilist assumption that having sufficient evidence that $p$ does not entail $p$ is true). Therefore, from the point of view of conforming with MAY, a permission to believe that $\mathrm{p}$ if and only if one has sufficient evidence that p (i.e. PERMISSIVE EVIDENCE) is a needlessly risky permission. So PERMISSIVE EVIDENCE cannot be explained by MAY.

Secondly, even if PERMISSIVE EVIDENCE could be explained by MAY, PERMISSIVE EVIDENCE still cannot explain justification, and for the very same reason that a permissive truth norm cannot explain justification. Because it's permissive, the best way of following PERMISSIVE EVIDENCE is to suspend judgement about everything; that guarantees conformity with PERMISSIVE EVIDENCE. This means that a permissive evidential norm cannot explain justification, because, again, we wouldn't take someone who suspended judgement about everything to be justified in doing so.

A third response one could give here is to claim that my argument depends on my assumption that one should take the best means of conforming to the objective truth norm. One might admit that suspending judgement is not the best means of conforming to a permissive truth norm, but (a) claim it is permissible to take merely good means, and (b) claim that forming a belief will be in many cases a good means of conforming to a permissive truth norm.

I don't think this is a good response. I'll grant that we can adopt the weaker constraint that one should take merely good means of conforming to objective norms. But I don't think that forming beliefs really is a good means of conforming to permissive truth norms. More specifically, I don't think that forming beliefs in most situations in which we would pre-theoretically take ourselves to be justified in doing so is a good means of conforming to permissive truth norms. If we admit that it's permissible to take merely good means of conforming to a permissive truth norm, at the very most this move will mean that one is justified in believing that $\mathrm{p}$ if one has overwhelmingly strong evidence in support of $\mathrm{p}$, what we would typically think of as evidence that would justify certainty. This is because true belief and suspension of judgement are just as much ways of conforming to a permissive truth norm; neither state can be (epistemologically) 
preferred to one another. This makes it's hard to see how anything other than only forming a belief that $\mathrm{p}$ when one has overwhelmingly strong evidence that $\mathrm{p}$ could count as good means of conforming to a permissive truth norm. But such a picture would not tally with our pre-theoretical picture of epistemic justification, according to which evidence that would justify belief is lower than the overwhelming degree of evidence that would justify certainty. Therefore, opting for the weaker constraint that one should take good means to conform to the objective truth norm does not save permissive truth norms from my charge that they cannot explain justification.

A fourth response is given by Thomas Raleigh. He claims that someone who takes the pyrrhonian option of suspending judgement about $\mathrm{p}$ no matter how strongly the evidence supports $\mathrm{p}$ does violate a permissive truth norm. This is because, he claims, suspending judgement about $\mathrm{p}$ no matter how strongly the evidence supports $\mathrm{p}$ is an attitude which "embodies a false belief about what the evidence supports" (Raleigh 2013, p. 263). Therefore, although the pyrrhonian does not have a false belief about p, he does have a false second-order epistemological belief about the evidence in support of p. So he is violating the permissive truth norm with regards to the second-order belief.

I admit that someone who suspends judgement about p no matter how strongly the evidence supports $\mathrm{p}$ has a false belief about what the evidence supports. But it's question-begging to assume this in defence of a permissive truth norm. This is because if a permissive truth norm were the fundamental norm that explains justification, the false belief about the evidence, which Raleigh claims the pyrrhonian has, would no longer be false.

To make this clear we need to be specific about which belief of the pyrrhonian's is supposed to be false. It cannot be a belief that the evidence supports $\mathrm{p}$ to a certain degree-e.g. a belief that the evidence makes p 95\% likely, for example-because the pyrrhonian can suspend judgement about $\mathrm{p}$ and retain that belief. It must be the pyrrhonian's belief that the evidence does not support $\mathrm{p}$ to a degree that's sufficient to make one justified in believing that $\mathrm{p}$. But if a permissive truth norm were the fundamental norm on belief, then no amount of evidence in support of $\mathrm{p}$ could make one justified in believing that $\mathrm{p}$, given that suspending judgement about $\mathrm{p}$ guarantees conformity with a permissive truth norm and believing $\mathrm{p}$ does not. To assume that the pyrrhonian's epistemological beliefs about epistemic support would be false, as Raleigh does, is question begging.

A fifth response a defender of a permissive truth norm could give is to claim that it's impossible for one to suspend judgement about everything; one just has to have some beliefs in order to live one's life (cf. Burnyeat 1980). A classic statement of this view comes from Hume: "The great subverter of Pyrrhonism or the excessive principles of scepticism is action, and employment, and the occupations of common life" (Hume 1748, pp. 158-59).

Does this help the defender of the permissive truth norm? I don't think it does. This is because even if it's true that one cannot suspend judgement about everything, that doesn't deal with the fundamental problem a permissive norm has with explaining justification.

This is because all that is strictly required for a permissive truth norm to fail to explain justification is for there to be some cases in which (a) one would be justified 
in believing that $\mathrm{p}$, and (b) it's possible for one to suspend judgement about p. A permissive truth norm would fail to explain justification if there is any such case, because such a case would show having a justified belief does not coincide with taking the best means to conform to a permissive truth norm. It's highly implausible to deny that there are any such cases, even if we grant the Humean point that it's impossible to suspend judgement about everything. Therefore, the impossibility of suspending judgement about everything doesn't touch my argument against permissive truth norms.

We can summarise the conclusion of this section as follows: if we want norms on beliefs to explain justification, that explanation is only going to work if not all norms on belief are permissive norms-i.e. norms that only prohibit having certain beliefs, but never positively prescribe believing anything. If there are only permissive norms on belief - whether they be truth norms, evidential norms, or something else - the best way of conforming with them will be the pyrrhonian option of suspending judgement about as much as one can; doing anything else will be needlessly risky.

\section{Against Wedgwood's conditional truth norm}

A second way of reformulating a truth norm so that it doesn't prescribe believing all the truths is to make it conditional, i.e. a norm which only comes into force if certain other conditions are met (conditions other than truth of course). The following norm, put forward by Ralph Wedgwood, is an example:

CONSIDERS: If one consciously considers $p$, then one ought to believe that $\mathrm{p}$ if and only if p is true. (Wedgwood 2013, p. 127)

CONSIDERS, unlike OUGHT, does not entail that one ought to believe all the truths, because there are many true propositions one does not consciously consider.

Because of this feature, CONSIDERS looks like it won't prescribe believing ungraspably complex truths or most cases of trivial truths. The former look like truths which we cannot consciously consider and the latter look like truths which we don't in fact consciously consider. On the other hand, Bykvist and Hattiangadi argue that CONSIDERS still faces problems with blindspots (Bykvist and Hattiangadi 2007, pp. 281-282, 2013, Sect. 3; though see Wedgwood 2013, Sects. 4-7 for a reply).

I'm not going to go into detail about whether CONSIDERS can deal with all three problematic kinds of truth. This is because even if it can, CONSIDERS also fails to explain justification, much as permissive truth norms did, though for rather different reasons.

\footnotetext{
4 Wedgwood doesn't actually defend CONSIDERS. He defends the following truth norm, which doesn't feature the concept 'ought', but instead features the concept 'correct':
}

CORRECT: A belief that $\mathrm{p}$ is correct if and only if p is true. (Wedgwood 2002, p. 272)

And although he doesn't put it into the content of his truth norm, Wedgwood makes it clear that he regards CORRECT as only concerning propositions one consciously considers (2002, p. 273, 2008, p. 5, fn.8). For simplicity, I'll discuss CONSIDERS rather than CORRECT, since it's a more direct reformulation of the norm we started with, OUGHT. 
Therefore, insofar as a truth norm is supposed to explain justification, CONSIDERS is inadequate.

The particular reason why CONSIDERS cannot explain justification is because it has implausible consequences in some situations in which someone has overwhelming evidence that $\mathrm{p}$, fails to believe that $\mathrm{p}$, but does not consciously consider $\mathrm{p}$. This result, as I'll now show, is implausible.

I'll illustrate with an example. Say's there's a boss of a company, called Diane, who has overwhelming evidence that one of her employees has repeatedly abused his position. In particular, Diane carries out periodic reviews of the company's accounts, and has strong evidence that a particular employee, John, has been secretly and repeatedly embezzling company money and spending it himself. However, Diane avoids ever consciously considering whether John has abused his position for some pragmatic reason: perhaps she avoids considering this because John's a close friend and she wouldn't be able to bear the thought that he'd steal from the company, or in order to avoid having to confront him about it. And the fact that Diane, for these pragmatic reasons, avoids thinking about it means that she fails to believe what her evidence overwhelmingly indicates, i.e. that John has abused his position. Furthermore, let's say that Diane's failure to believe that John has abused his position is manifested in her thought and behaviour in various ways, just none of which involve her considering whether he's abused his position. For example, she writes that she is happy with his performance in his reviews, she's not planning to sack him, etc.

I take it that the intuitive response to such a case is that Diane is epistemically unjustified for failing to believe that John has abused his position. Diane's failure to consider whether John has abused his position is, I admit, pragmatically motivated, and is a practical or moral failing. But this does not mean that Diane is not also epistemically unjustified. It is commonplace to think that belief formation being influenced by pragmatic considerations can result in epistemic irrationality, as in cases of wishful thinking and self-deception. And this looks like what happens in the case of Diane. Therefore, if CONSIDERS is the fundamental norm that explains justification, then it should explain why Diane is epistemically unjustified.

However, it doesn't looks like CONSIDERS can explain this. This is because Diane has not taken any bad means of conforming to CONSIDERS. This is precisely because CONSIDERS does not oblige one to believe anything about $\mathrm{p}$ if one doesn't consciously consider p; if one doesn't consciously consider $\mathrm{p}$, one is necessarily off the hook. In other words, because CONSIDERS means one cannot be unjustified in failing to believe that $\mathrm{p}$ unless one consciously considers $\mathrm{p}$, it makes justification too restrictive.

A defender of CONSIDERS might claim here that Diane should have consciously considered whether her employee has abused her position, perhaps because of her fiduciary responsibility to the company's shareholders. If this is the case, we can still claim that Diane has done something wrong, but what she has done wrong is not explained by CONSIDERS, but by a distinct norm about what she ought to consciously consider.

I have two responses to this objection. Firstly, it seems to me that what Diane has done wrong is, at least in part, an epistemic failure. But if the only thing Diane has done wrong, according to the defender of CONSIDERS, is to violate a distinct norm about what she ought to consciously consider, then that doesn't look like an epistemic 
failure; it looks more like a practical or moral failure. Claiming that Diane has only violated a practical norm about what she ought to consciously consider looks like an overly narrow picture of what kinds of failure occur in such a case.

Secondly, and more importantly, if the defence of CONSIDERS depends on appealing to distinct norms about what one ought to consciously consider, that means that CONSIDERS cannot be the fundamental norm on belief that explains justification, i.e. it cannot by itself explain why belief is subject to other epistemic norms. And just as with permissive truth norms, the key point I have wanted to make is that CONSIDERS cannot be the fundamental norm that explains justification. Those like Wedgwood who defend a truth norm that only applies to propositions which one consciously considers do claim it is fundamental norm on belief that explains justification (Wedgwood 2002, pp. 271-283). That claim is undermined if the defender of CONSIDERS has to appeal to other norms about what one ought to consciously consider in order to deal with cases like that of Diane.

In summary, reformulating a truth norm so that it only applies to propositions one consciously considers makes it incapable of carrying out the role of explaining justification. It means one can only be unjustified in relation to propositions one actually consciously considers. But this, as the case of Diane shows, is implausible. This doesn't show that CONSIDERS is false. It may well still be the case that for every proposition one considers, one should believe it if and only if it's true. But it does show that CONSIDERS cannot be the fundamental norm which explains justification. Therefore, insofar as a truth norm is supposed to play that role, CONSIDERS is inadequate.

\section{In defence of an alternative conditional truth norm: DOXASTIC ATTITUDE}

Although we've seen that CONSIDERS fails to explain justification, I want to suggest making a truth norm conditional is the right way to deal with the believing-allthe-truths problem. In particular, I'll defend the following conditional truth norm, discussed (but not defended) by Conor McHugh:

DOXASTIC ATTITUDE: If one has some doxastic attitude towards $p$, one ought to believe that $\mathrm{p}$ if and only if $\mathrm{p}$ is true. (McHugh 2012, p. 12)

Having 'some doxastic attitude towards p' involves either believing that $\mathrm{p}$, or disbelieving $\mathrm{p}$ (i.e. believing that not-p), or suspending judgement as to whether $\mathrm{p}$. I'll give more detail about the last of these three options shortly, and particular about why we should think of it as a doxastic attitude.

My defence of DOXASTIC ATTITUDE has two main steps. Firstly, I'll argue, in Sect. 4.1, that DOXASTIC ATTITUDE does not have the problem CONSIDERS had with the case of Diane. Whereas it was implausible that one could be unjustified only in relation to propositions one actually consciously considers, it is plausible, I'll suggest, that one can be unjustified only in relation to propositions one has some doxastic attitude towards. This means that DOXASTIC ATTITUDE doesn't fail to explain justification in the way that CONSIDERS does. 
Secondly, I'll argue, in Sect. 4.2, that DOXASTIC ATTITUDE does not prescribe believing the three problematic kinds of truth discussed above: ungraspably complex truths, trivial truths, and true blindspots. I'll admit that DOXASTIC ATTITUDE has an initial problem with dealing with trivial truths and true blindspots. Given one will have some attitude towards some truths of these kinds, DOXASTIC ATTITUDE prescribes believing some of them. But I'll argue that this can be dealt with by appealing to the way in which a truth norm like DOXASTIC ATTITUDE explains justification. Firstly, I'll argue that following DOXASTIC ATTITUDE will never involve believing blindspots. Secondly, I'll argue that following DOXASTIC ATTITUDE will only involve believing trivial truths which one would look unjustified if one didn't believe.

This second point is one we could also make in relation to some other truth norms; in particular, in relation to CONSIDERS. The key reason to prefer DOXASTIC ATTITUDE is that it both provides an answer believing-all-the-truths problem and is capable of explaining justification.

\subsection{Why DOXASTIC ATTITUDE does not make justification overly restrictive}

I'll first explain why DOXASTIC ATTITUDE does not have the problem CONSIDERS had with the case of Diane. The problem with CONSIDERS was that if it were the fundamental norm explaining justification, then justification would be overly restrictive. In particular, it would have the result that one could only be unjustified in relation to propositions one consciously considers. But the case of Diane showed this to be implausible.

DOXASTIC ATTITUDE does not, I suggest, have an analogous problem. It is plausible, I'll argue, that one can only count as being unjustified in failing to believe that $\mathrm{p}$ if one has some doxastic attitude about whether $\mathrm{p}$, i.e. if one counts as believing, disbelieving, or suspending judgement about whether p. In order to show this, I'll need to briefly discuss the reasons for thinking that suspension of judgement is a distinctive doxastic attitude.

It's plausible that to suspend judgement about whether $p$ is not just a matter of neither believing nor disbelieving $\mathrm{p}$. As Wedgwood points out, even rocks and numbers count as neither believing nor disbelieving propositions, but they don't count as suspending judgement about them (2002, p. 272). Rather, suspending judgement about whether $p$ seems to involve having some attitude about whether $\mathrm{p}$, but just an attitude of neutrality rather than belief (though it needn't involve being exactly neutral as to whether $\mathrm{p}$, i.e. thinking that $\mathrm{p}$ is just as likely as not-p). In this vein, Scott Sturgeon describes suspension of judgement as committed neutrality (2010, p. 136).

There is a further question, which I won't go into, about what constitutes this attitude of committed neutrality about whether p. Some claim that it is reducible to some other doxastic attitude. This could be a middling credence/confidence as to whether p (Christensen 2009, p. 757), or a middling confidence spread (otherwise known as a middling 'mushy credence') (Sturgeon 2010). It could also be a higher-order belief, such as the belief that the evidence doesn't support having a belief about whether $\mathrm{p}$ (Raleigh 2013, p. 263). Others claim that suspending judgement about whether $\mathrm{p}$ is a distinct and sui generis doxastic attitude towards p (Friedman 2013). 
I'm going to set this question aside, because I'm not concerned with the particular doxastic attitude suspending judgement should be analysed as, if any (though for more detail, see Friedman 2013); I'm concerned with what differentiates cases in which I suspend judgement about $\mathrm{p}$ - i.e. cases in which I have the distinct attitude of neutrality about whether $\mathrm{p}$ - from cases in which I merely lack belief about whether $\mathrm{p}$.

So what differentiates someone who suspends judgement about whether $\mathrm{p}$ from someone who merely lacks belief about whether $\mathrm{p}$ ? I want to suggest that the guide to when someone counts as suspending judgement is if we need to appeal to an attitude of neutrality or agnosticism about whether $\mathrm{p}$ as part of their cognitive economy, e.g. to explain why they acted in a certain way or had other attitudes. For example, say a holidaymaker was planning on going on holiday after the Brexit referendum, and changed half of their currency before the referendum and waited to change the rest after the referendum. In order to explain this holidaymaker's behaviour, we need to appeal to attitude of neutrality about who would win the referendum.

The role of an attitude of neutrality in one's cognitive economy can help distinguish the above case from cases when someone lacks any attitude towards a proposition. For example, it's plausible Donald Trump has no doxastic attitude about whether the Queen is currently in the White Drawing Room in Buckingham Palace. Like our holidaymaker, Donald Trump neither believes or disbelieves the proposition. The key difference, I suggest, is that in the case of our holidaymaker, an attitude of neutrality is required to explain his behaviour; whereas with Donald Trump we don't have to appeal an attitude of neutrality about whether the Queen is currently in the White Drawing Room in order to explain anything he does, thinks, or feels.

Other examples of where lack of belief as to whether $p$ does not amount to suspension of judgement include cases when one lacks the requisite concepts or when one can't fully grasp p because one's not sufficiently acquainted with its content. The former might include children who lack beliefs about whether Britain will enter a recession after Brexit. An example of the latter might be my lack of belief as to whether a particular hair on David Cameron's left arm is exactly $1 \mathrm{~cm}$ long. What unites these cases and Donald Trump's lack of belief about the Queen's whereabouts is that we don't have to appeal to any attitude of neutrality in the believers' cognitive economies in order to explain what they think, feel, or do, whereas we do in a case like the holidaymaker. An attitude of neutrality or agnosticism playing a role in one's cognitive economy is what I regard as the essence of suspension of judgement, and this is how I intend it to be understood in my defence of DOXASTIC ATTITUDE.

This is a rough sketch, but it will be sufficient to defend my key claim: that one can that only be unjustified in failing to believe that $\mathrm{p}$ if one has some other attitude towards p, i.e. either disbelief or suspension of judgement. Once we take into account what would be really be involved in someone not having any doxastic attitude about whether $\mathrm{p}$, it is no longer plausible, I suggest, that such a person could count as unjustified for failing to believe that $\mathrm{p}$. This means that DOXASTIC ATTITUDE, unlike CONSIDERS, does not make justification overly restrictive.

This can be illustrated with the case of Diane, but the point generalizes. In the case of Diane, at least as I described it above, I think it's plausible that Diane counts as having some doxastic attitude about whether John has abused his position, whether that be a negative attitude of disbelief or a neutral attitude of suspension of judgement. 
It seems, as least in the case as I described it above, we would need to appeal to one of these doxastic attitudes about whether John has abused his position as part of Diane's cognitive economy in order to explain her actions and attitudes, e.g. to explain why she's stated she's happy with John's performance in his reviews, why not planning on sacking him, etc.

One might doubt whether I can say this, given how I've described Diane as never having consciously considered whether John has abused his position. This may seem to undermine my claim that Diane has some doxastic attitude-either disbelief or suspension of judgement-about this proposition. One may think having an attitude requires prior conscious consideration.

But this doesn't look true. Disbelief clearly doesn't require prior conscious consideration, and I suggest we should say the same about suspension of judgement. It's clear that one can believe that belief $\mathrm{p}$ without having consciously considered $\mathrm{p}$. To use Robert Audi's example, "one might come to believe, through hearing a distinctive siren, that an ambulance went by, but without thinking of this proposition or considering the matter" (1994, p. 421). Since disbelief just is belief that not-p, disbelief needn't require prior conscious consideration. So if Diane counts as disbelieving the proposition as question, there is clearly no problem here.

Does Diane's failure to consciously consider whether John has abused his position mean she can't count as suspending judgement? I suggest that we shouldn't think that suspension of judgement requires conscious consideration either. ${ }^{5}$ Recall that the essence of the attitude of suspension of judgement, as I mean it, is whether an attitude of neutrality plays a role in someone's cognitive economy. This doesn't look like it requires prior conscious consideration. We can illustrate by modifying Audi's example slightly. Say I hear a siren, but I don't know the difference between ambulance and police sirens (though I recognize both as emergency-services vehicles). In such a case, I think it's plausible that an attitude of neutrality about whether an ambulance went by can play a role in my cognitive economy. It might explain why, for example, I begin to worry about whether something's happened to my infirm neighbour, and why I look out the window to check. This doesn't look like it requires prior conscious consideration of whether an ambulance has gone by, any more than belief did in Audi's original example.

Applying these considerations to case of Diane, I don't think prior conscious consideration is required for her to count as suspending judgement. All that is required is for an attitude of neutrality about whether John has abused his position to play a role in her cognitive economy, and I think it clearly does, e.g. she states that she is happy about his performance and she does not intend to sack him. These actions and attitudes only make sense, I suggest, if she either disbelieves or suspends judgement about whether John has abused his position. Therefore, I think it's plausible that Diane counts as having some doxastic attitude.

Furthermore, I think it's plausible that Diane counts as unjustified for failing to believe that John has abused his position only given the assumption that she has some doxastic attitude about this. This can be shown by thinking about what would have

\footnotetext{
${ }^{5}$ Some have claimed that suspension of judgement requires prior consideration. For example, Wedgwood understand suspension of judgement as "when one consciously considers $p$, but neither believes nor disbelieves p" (2002, p. 272). Others deny this (Friedman 2013, p. 170).
} 
to be different in order for it to be plausible that Diane counts as not having any doxastic attitude about whether John has abused his position, i.e. to not even count as suspending judgement about it.

What would have to be the case for Diane to lack any doxastic attitude about whether her employee abused his position? Recall the kinds of cases I discussed earlier in which people neither believe nor disbelieve $\mathrm{p}$, but don't count as suspending judgement about whether $\mathrm{p}$. These included cases in which the proposition in question clearly played no role in one's doxastic mental life (such as Donald Trump's lack of belief about the Queen's whereabouts), cases in which people lack the requisite concepts involved in $\mathrm{p}$, and cases in which people aren't sufficiently acquainted with p's content. Because we don't need to appeal to an attitude of neutrality as to whether $\mathrm{p}$ as part of their cognitive economy, such people plausibly count as not having any attitude towards $p$ at all.

We could modify the case of Diane to be more like these cases. We could make it more like Donald Trump's lack of belief about the Queen's whereabouts by making Diane no longer have a position of authority, so she doesn't carry out reviews of the accounts and employees' performance. We could make her case more like the case of lacking the requisite concepts, for example, supposing that Diane doesn't fully understand what it is for someone to abuse their position; perhaps she doesn't have the concept of legal or moral obligation, so she doesn't understand that her employees have certain duties in virtue of having the roles that they do.

In these modified cases, I admit that it would be plausible that Diane would count as not having any attitude about whether her John has abused her position, not even an attitude of neutrality. But I don't think it's plausible that in such circumstances, Diane would count as unjustified in failing to believe that her employee has abused his position. In the case in which Diane no longer reviews the accounts or employee performance, it's hard for still think of her as having sufficient evidence that he's abused his position. In the case where she lacks the relevant concepts, I don't think it's plausible that she would be unjustified even if she still has overwhelming evidence that he has (though she may only recognise in retrospect that it was evidence). If Diane genuinely lacked the relevant concepts, then the case would look more like one of non-culpable ignorance. Therefore, changing the case in this way so that Diane counts as not having any doxastic attitude about whether John has abused his position makes it no longer plausible that she's unjustified.

These are, of course, just two ways in which the case of Diane could be changed so that she has no attitude about whether John has abused his position. And more generally the case of Diane, as originally described, is just one example of someone who looks unjustified in failing to believe that p. But I think there is a principled reason to make a more general conclusion that one can only be unjustified in failing to believing that $\mathrm{p}$ if one has some doxastic attitude towards $\mathrm{p}$.

This is because in order to make it plausible a subject doesn't have any attitude at all about a proposition, you need to invoke some sort of gap between the subject and the proposition in question. That is required to support the claim that the subject doesn't have any doxastic attitude about whether $\mathrm{p}$, i.e. the claim that proposition in question plays no role in the subject's (doxastic) mental life. This was evident in my modified examples, which both needed to appeal to this kind of gap in order for Diane 
to count as not having any attitude about whether John abused his position. But the existence of such a gap between the subject and the proposition is also likely to make it implausible that the subject could count as unjustified for failing to believe that $p$, i.e. it's likely to make it into a case of non-culpable ignorance. It doesn't look plausible that there will be any cases in which someone both plausibly looks like they don't have any doxastic attitude about whether $\mathrm{p}$ and plausibly looks unjustified in failing to believe that $\mathrm{p}$.

This should lead us to conclude, I suggest, that one can only be unjustified in failing to believe that $\mathrm{p}$ if one has some doxastic attitude about whether $\mathrm{p}$. And if this is case, DOXASTIC ATTITUDE does not have an analogous problem to CONSIDERS. CONSIDERS made justification overly restrictive, because it meant that one could only be unjustified in failing to believe that $\mathrm{p}$ if one consciously considered $\mathrm{p}$. The case of Diane showed this to be false. On the other hand, if DOXASTIC ATTITUDE is the fundamental norm that explains justification, that would mean that one could only be unjustified in failing to believe that $\mathrm{p}$ if one has some doxastic attitude about whether $\mathrm{p}$. But this, as I've just shown, is plausibly true. Therefore, DOXASTIC ATTITUDE does not make justification overly restrictive.

\subsection{How DOXASTIC ATTITUDE answers the believing-all-the-truths problem}

We can now move on to explain how DOXASTIC ATTITUDE deals with the believingall-the-truths-problem. DOXASTIC ATTITUDE clearly doesn't entail that one ought to believe all the truths because there are many truths which one doesn't have any doxastic attitude about. But does it entail that one ought to believe the three problematic truths that we covered earlier: ungraspably complex truths, trivial truths, and true blindspots?

On the one hand, it easily deals with ungraspably complex truths. If $\mathrm{p}$ is ungraspably complex, it's impossible for me to have any doxastic attitude about whether $\mathrm{p}$. So DOXASTIC ATTITUDE will never prescribe believing ungraspably complex truths. Therefore, DOXASTIC ATTITUDE does not violate 'OUGHT' IMPLIES 'CAN' in the way that OUGHT did.

On the other hand, it might seem at first glance to have some trouble with dealing with trivial truths and true blindspots.

Let's start with trivial truths. There are many examples of trivial truths which DOXASTIC ATTITUDE does not and will never prescribe believing, such as a truth about the length of a hair on David Cameron's arm, because I don't have any doxastic attitude towards this truth, and almost certainly never will.

However, it looks like DOXASTIC ATTITUDE might prescribe believing some trivial truths. This is because I might count as suspending judgment about some trivial truths. For example, say I'm home for Christmas, and my brothers insist on playing a board game, but the only game we have is an out of date edition of Trivial Pursuit. During this game, my brother asks me what was the nationality of the bronze medal winner in men's 100 m breaststroke at the Seoul Olympics. I tell him I don't know the answer, and we proceed with the game.

The true proposition about the nationality of the bronze medal winner of the men's $100 \mathrm{~m}$ breaststroke shooting at the Seoul Olympics looks just as trivial as a proposition 
about a hair on David Cameron's arm, and I look just as justified in having no belief about it. But I do seem to have a doxastic attitude about the latter proposition, namely suspension of judgement, because we would need to appeal to an attitude of neutrality about whether this proposition is true in order to explain by behaviour, i.e. my telling my brother I didn't know the answer. So according to DOXASTIC ATTITUDE, I ought to believe it. But an obligation to have a true belief about the nationality of the bronze medal winner at the men's $100 \mathrm{~m}$ breaststroke at the Seoul Olympics looks to be the kind of implausible obligation we were trying to avoid.

Secondly, DOXASTIC ATTITUDE might seem to have some trouble dealing with true blindspots. Presumably, I could count as either disbelieving or suspending judgement about whether it's raining but nobody believes it's raining, if, say, I believe it's not raining. But the proposition could be true, given I'm not infallible. And if it's true, then DOXASTIC ATTITUDE prescribes believing it. So DOXASTIC ATTITUDE prescribes believing some true blindspots.

The way to deal with these problems is not, I suggest, to further reformulate DOXASTIC ATTITUDE so that it does not prescribe believing any trivial truths or true blindspots. The better way to deal with these problems, I will argue, involves appealing to the way in which a truth norm like DOXASTIC ATTITUDE is supposed to explain epistemic justification. Recall that a truth norm like DOXASTIC ATTITUDE is supposed to explain justification because one should follow subsidiary norms as a means to the end of conforming to it. This enables us to show that the fact DOXASTIC ATTITUDE prescribes believing some trivial truths and some true blindspots is unproblematic.

What I'll argue is that DOXASTIC ATTITUDE does prescribe believing some of these problematic truths, the means one should take to the end of conforming with DOXASTIC ATTITUDE will never involve believing true blindspots, and won't prescribe believing any problematic trivial truths.

\subsubsection{Why following DOXASTIC ATTITUDE will involve never believing blindspots}

Let's assume that I have some attitude about the proposition that it's raining and nobody believes that it is raining, i.e. that I count as either disbelieving or suspending judgement about it. If this is the case, and if the proposition is true, then DOXASTIC ATTITUDE prescribes believing it.

This is unproblematic, I suggest, because the means one should take in order to conform to DOXASTIC ATTITUDE will never involve believing the proposition that it raining and nobody believes that it is raining. And this is the case whether or not the proposition is true.

This is because if one does believe that it's raining and nobody believes that it's raining, one is guaranteed to fail in conforming with DOXASTIC ATTITUDE. As soon as one believes it, it becomes false, and it thereby becomes the case that one has failed to conform to DOXASTIC ATTITUDE. And, of course, this is the case whether or not this proposition was true before one believed it.

On the other hand, if one does not believe that it is raining and nobody believes that it's raining — by either disbelieving or suspending judgement about it - then one is not guaranteed to fail in conforming with DOXASTIC ATTITUDE. If it does turn out to be true that it is raining and nobody believes that it is, then in failing to believe 
this proposition one will fail to conform to DOXASTIC ATTITUDE. But it could be false that it's raining and nobody believes that it is. And in that case one has succeeded in conforming to DOXASTIC ATTITUDE, because one has avoided having a false belief about whether it's raining and nobody believes it is.

Therefore, clearly the best strategy from the point of view of conforming with DOXASTIC ATTITUDE is to not believe a blindspot proposition, as can be seen in the table below:

\begin{tabular}{|c|c|c|}
\hline \multicolumn{3}{|c|}{ Blindspot Options } \\
\hline & $\begin{array}{l}\text { Believing that it's raining } \\
\text { and nobody believes that } \\
\text { it's raining. }\end{array}$ & $\begin{array}{l}\text { Not believing that it's } \\
\text { raining and nobody believes } \\
\text { that it's raining }\end{array}$ \\
\hline $\begin{array}{l}\text { It's true that it's raining and } \\
\text { nobody believes it's raining }\end{array}$ & Impossible & $\begin{array}{l}\text { Failure to conform to } \\
\text { DOXASTIC ATTITUDE } \\
\text { (failure to have a true belief) }\end{array}$ \\
\hline $\begin{array}{l}\text { It's false that it's raining and } \\
\text { nobody believes it's raining }\end{array}$ & $\begin{array}{l}\text { Failure to conform to } \\
\text { DOXASTIC ATTITUDE } \\
\text { (false belief) }\end{array}$ & $\begin{array}{l}\text { Success in conforming to } \\
\text { DOXASTIC ATTITUDE } \\
\text { (avoidance of false belief) }\end{array}$ \\
\hline
\end{tabular}

As the table shows, the option of believing a blindspot is guaranteed to result in failing to conform with DOXASTIC ATTITUDE, whereas the option of not believing a blindspot could possibly succeed. Therefore, a believer trying to conform with DOXASTIC ATTITUDE clearly should not believe any blindspots.

Furthermore, we can be sure of this in advance, because it's written into the content of a blindspot. I don't need to try to conform to DOXASTIC ATTITUDE by believing a blindspot, and then realise, much to my chagrin, that I've failed only after I've formed a belief.

Therefore, although DOXASTIC ATTITUDE prescribes believing some true blindspots, the means one should take to conform to DOXASTIC ATTITUDE will never involve believing blindspots, even if they are true.

I'll now consider two possible objections to how I've dealt with blindspots. Firstly, one might object by pointing out DOXASTIC ATTITUDE still violates Bykvist and Hattiangadi's principle 'OUGHT' IMPLIES 'CAN SATISFY'.

My response is that, given what I've shown, it's not clear that violating this principle is problematic. Now we've shown that the means one should take to conform to DOXASTIC ATTITUDE will never involve believing blindspots, it's unclear that there remains any theoretical support for ruling out DOXASTIC ATTITUDE on the grounds that it violates this principle.

The motivations for an obligation-limiting principle like 'OUGHT' IMPLIES 'CAN SATISFY' - assuming that it has the same kind of motivations at the more familiar obligation-limiting principle 'OUGHT' IMPLIES 'CAN'-typically are that we need such a principle in order rule out certain norms, e.g. to rule out norms that are overdemanding, norms that are unfair, norms that cannot provide guidance, or norms that lead 
one on pointless errands (see Andrić 2017 for a summary). It's hard to see how any of these rationales can provide theoretical support for appealing to 'OUGHT' IMPLIES 'CAN SATISFY' in order to rule out DOXASTIC ATTITUDE, given that one can know in advance that the means one should take to follow DOXASTIC ATTITUDE will never involve believing a blindspot.

Therefore, the fact that it violates Bykvist and Hattiangadi's principle 'OUGHT' IMPLIES 'CAN SATISFY' doesn't provide us with reason to reject DOXASTIC ATTITUDE, because it's not clear that the principle itself has sufficient theoretical support.

A second objection will require more discussion. One might claim that what I've said doesn't really deal with the problem blindspots create for a truth norm. This is because for all I've said it's still the case that DOXASTIC ATTITUDE prescribes believing true blindspots. All I've shown, this objection continues, is that there's a conflict between DOXASTIC ATTITUDE and the subsidiary norms I' $m$ claiming one should follow as a means of conforming with DOXASTIC ATTITUDE. One might think this conflict puts doubt on my claim that DOXASTIC ATTITUDE explains subsidiary epistemic norms like evidence and consistency norms. This is because, if there are cases of conflict where DOXASTIC ATTITUDE prescribes one thing and the subsidiary norms prescribe another, then, it is claimed, the subsidiary epistemic norms don't look like good means of conforming to DOXASTIC ATTITUDE. And this seems to undermine the claim that DOXASTIC ATTITUDE explains those subsidiary epistemic norms (see Hattiangadi 2010, pp. 425-427; Gibbons 2013, Chap. 1; Glüer and Wikforss 2013, Sect. 2).

I don't think this issue of 'conflict' undermines the way I've dealt with blindspots. My first response is dialectical. If it's problematic that truth norms and subsidiary evidence norms have conflicting prescriptions, this is a distinct problem which is independent of the believing-all-the-truths problem. The believing-all-the-truths problem was the claim that there are particular problematic kinds of truths which it's implausible to claim we ought to believe. But we don't need to appeal to particular problematic kinds of truths-e.g. true blindspots, trivial truths, etc. - to create cases in which truth norms and evidence norms give conflicting prescriptions. Any case of a justified false belief or unjustified true belief provides this kind of conflict. Therefore, if the real problem with true blindspots is that they involve this kind of conflict, then (a) this will no longer be the believing-all-the-truths problem, and (b) raising this problem by appealing to blindspots will be a completely unnecessary detour because any justified true belief or unjustified false belief create the same conflict.

My second response is that the kind of conflict at issue here is unproblematic. I agree that in relation to a true blindspot, DOXASTIC ATTITUDE and the subsidiary norms give differing prescriptions. In this sense there is a conflict. But given the background picture of how a truth norm is supposed to explain justification, I don't think these differing prescriptions create a conflict which casts doubt on my claim that not believing a blindspot is the best means of conforming with DOXASTIC ATTITUDE.

Let's recall how a truth norm is supposed to explain justification. A truth norm like DOXASTIC ATTITUDE is an objective norm; that is, it is a norm for which it's not transparent whether we are conformity with it. Given this, we have to follow whatever subjective epistemic norms look from our perspective like the best means to the end of conforming to the truth norm in question. These subjective norms are typically claimed to include logical and evidential norms. I have been claiming in this section that these 
subjective norms will also include a prescription never to believe a blindspot. ${ }^{6}$ As I said above, these subjective norms are not an infallible means of conforming to a truth norm; they are just supposed to be the best means available to non-omniscient believers like ourselves.

Given this picture, not all cases in which objective and subjective norms differ in their prescriptions will cast doubt on the explanatory role of a truth norm. Specifically, differing prescriptions would only undermine the truth norm's explanatory role if those differing prescriptions cast doubt on the idea that the subjective norms are the best means of conforming to an objective norm that are available to non-omniscient believers like us. Some cases of differing prescriptions between objective and subjective norms show this and some do not. True blindspots are one of the cases which do not.

It is clear that differing prescriptions do not always cast doubt on the idea that subjective epistemic norms are the best means of conforming to a truth norm. Take a case of a justified false belief. Say I believe I'm going to dinner with my typically trustworthy and reliable friend, when in fact she is taking me to a surprise party she's organized. All the evidence suggested I was going to dinner, so evidence norms would prescribe belief. I wasn't going to dinner, so a truth norm would not prescribe belief. But this doesn't undermine the idea that I was taking the best means available to me of conforming to a truth norm; I just got unlucky (cf. Raleigh 2013, pp. 255-256). The same is the case in relation to objective practical norms. For example, those who defend 'objective' consequentialism claim that one morally ought to do what in fact will have the best consequences, but non-omniscient agents ought to do what looks like the best means of conforming with what objective consequentialism demands (see, e.g. Railton 1984, p. 143; Feldman 1986, pp. 45-48; Driver 2012, Chap. 5). This picture is not undermined by the mere existence of misleading evidence about consequences. For example, if all the evidence suggested that I would enjoy the surprise party, but in the end I happen not to, that doesn't undermine the claim that my friend was doing what looked like the best way of conforming with objective consequentialism; she was just unlucky. Objective consequentialism does not have a case to answer here.

On the other hand, there are cases - in both ethics and epistemology — which do look like they cast doubt on the claim that subjective norms are what look like the best means of conforming to objective norms. Take, for example, so-called 'three option' cases; cases in which one is not in a position to know what the best and worst options are, but one knows for sure what the middling option is. A classic example, given by Frank Jackson, is of a doctor who knows that out of two drugs, one will cure the patient and one will kill them, and a third drug will relieve but not cure the patient's illness (Jackson 1991, pp. 462-463). Similar three-option cases also pose problems for truth norms. These are cases in which the one has neither sufficient evidence for or against a proposition, such as the proposition that a fair coin just thrown has landed

\footnotetext{
${ }^{6}$ It would be a mistake to suggest that this is contradictory. DOXASTIC ATTITUDE gives the objective sense of what one 'ought' to believe. There is a distinct subjective 'ought', i.e. what one ought to believe given one's epistemic situation. And the content of the truth norm explanation of justification is that what one subjectively 'ought' to believe is defined by a means-end relation to DOXASTIC ATTITUDE: one subjectively ought to believe what looks like the best means from one's perspective of conforming with DOXASTIC ATTITUDE
} 
heads (Hattiangadi 2010, pp. 426-427). In these two cases, objective consequentialism and a truth norm have a case to answer. This is because they are cases of differing prescriptions in which what looks from the subject's perspective to be the best means of conforming to the objective norm diverges from our intuitive standards of justification. ${ }^{7}$

We can now return to blindspots. I've outlined cases in which differing prescriptions cast doubt on the claim that subjective norms are a good means of following an objective truth norm and cases in which they don't. What distinguishes these kinds of case? It seems that in the latter, but not the former, the conflict between the differing prescriptions is transparent to the subject. Roughly, they give us reason to doubt that following the subjective norms really is a good means of conforming to the objective norms because these norms are pushing the subject in differing directions.

Given this, we need to ask whether true blindspots create a conflict which is transparent to the subject. The clear answer is that they do not. They do not provide cases in which objective and subjective norms push believers in different directions. With regards to a true blindspot, it doesn't look like a situation in which I can say to myself: "DOXASTIC ATTITUDE is telling me to take one course of action; the subsidiary norms - the evidence norms - are telling me to take another distinct course of action. Which one option should I go for?" There could only be this kind of transparent conflict between an evidence norm and a truth norm if I were in a position to know that following an evidence norm was a bad way of conforming with the truth norm with regards to a specific proposition. But I'm never going to be in this position with regards to a true blindspot.

Rather, I've shown in the table above that we are actually in a position to know that not believing a true blindspot is the best way of conforming to DOXASTIC ATTITUDE that we have available to us. This is because the blindspot might in fact be false; and if it's true, it's impossible to believe it truly.

Because of this, in the case of a true blindspot, the conflict between DOXASTIC ATTITUDE and subsidiary norms is not one which undermines DOXASTIC ATTITUDE's explanation of justification. Because it is not a conflict which is transparent to the believer-i.e. not a conflict which pushes the believer in different directions - it doesn't cast doubt on the claim that not believing a true blindspot is the best means of conforming to DOXASTIC ATTITUDE available to non-omnisicient believers like ourselves. Rather, failing to believe a true blindspot instead looks more like the case of an evidentially supported false belief, i.e. a case in which the best means of conforming to DOXASTIC ATTITUDE lead us astray, not because we could do better, but because we're not omniscient. Never believing any blindspots $i s$ the best means of conforming to DOXASTIC ATTITUDE available to non-omnisicent believers like us - this is what I've shown in the table above-and the issue of 'conflict' gives us no reason to deny this.

\footnotetext{
7 That's not to say that these cases are insurmountable. I think a truth norm account can deal with them. It would take me too far afield to explain in detail, but what I regard as the best way to deal with epistemic three-option cases is to claim that there is a contrary-to-duty obligation to err on the side of caution. In other words, there is a second objective truth norm which states that if one violates DOXASTIC ATTITUDE, one ought to do so by not having a belief rather than having a false belief. Roughly equivalent ways of doing this in non-deontic terms are to give suspension of judgment an intermediate degree of correctness (Wedgwood 2002, pp. 272-273) or intermediate epistemic value (McHugh 2012, p. 20).
} 


\subsubsection{Why following DOXASTIC ATTITUDE will not involve believing problematic trivial truths}

I won't deny that DOXASTIC ATTITUDE prescribes believing some trivial truths. With most of the canonical examples of trivial truths - about grains of sand, defunct phone numbers, etc.-DOXASTIC ATTITUDE will not prescribe belief, but it will, I think, prescribe believing some trivial truths. However, it does so in a way that's unproblematic. The cases in which following DOXASTIC ATTITUDE does involve believing trivial truths are cases in which one would look unjustified if one didn't believe the trivial truth in question.

Explaining this requires being more specific about the subsidiary norms one should follow as a means to the end of conforming to DOXASTIC ATTITUDE. In particular, we need to claim that the following is one of the subsidiary norms:

SUFFICIENT EVIDENCE: If one has some doxastic attitude about whether $\mathrm{p}$, one

ought to believe that $\mathrm{p}$ if and only if one has sufficient evidence that $\mathrm{p}$.

What does it mean to have 'sufficient evidence'? The idea is supposed to express an intuitive requirement on justification. Having a justified belief that p requires more than having some evidence that supports p. Say I'm in Spain during midsummer, and I wake up and haven't drawn the curtains yet. It being midsummer is some evidence that it's not raining outside, but not enough for justification. In order to be justified in believing that it's not raining outside, I need evidence that supports the proposition above a certain threshold that counts as sufficient, which in this case I can do by opening the curtains. SUFFICIENT EVIDENCE encodes this requirement.

Why should one follow SUFFICIENT EVIDENCE as means of conforming to DOXASTIC ATTITUDE? Briefly, because DOXASTIC ATTITUDE prescribes both believing truths and avoiding falsehoods. To strike a balance between these dual competing aims, one would need to follow a subsidiary norm that did two things. Firstly, it would need to prescribe believing that $\mathrm{p}$ if one has evidence that counts in favour of p's truth, in order to give one a good chance of believing some truths. Secondly, it would need to prescribe believing that $\mathrm{p}$ only if one's evidence supports $\mathrm{p}$ above a certain threshold, in order to give one a good chance of avoiding false beliefs. SUFFICIENT EVIDENCE does just these two things. So one should follow SUFFICIENT EVIDENCE as a means to the end of conforming to DOXASTIC ATTITUDE.

A full defence of a truth norm account of justification will include a more detailed explanation of when one's evidence is sufficient, and a fuller defence of the claim that one should follow SUFFICIENT EVIDENCE in order to conform to DOXASTIC ATTITUDE. But I needn't do this work in order to explain how DOXASTIC ATTITUDE deals with trivial truths. Firstly, the assumption that one should follow a norm that prescribes believing on the basis of sufficient evidence in order to conform with a truth norm is dialectically appropriate. For if this assumption is false, then a truth norm won't be able to explain justification, but for reasons that are independent of the believing-all-thetruths problem. And secondly, however we set the threshold for sufficient evidence, we will typically have an extremely small amount of relevant evidence about trivial truths, if we have any at all. For instance, consider again the proposition about the nationality of the bronze medal winner in the men's $100 \mathrm{~m}$ breaststroke at the Seoul 
Olympics. I probably count as having some relevant evidence about this proposition, e.g. I know he's more likely to be from a historically successful Olympic nation like the USA or the Soviet Union than, say, Mongolia or Luxembourg. But I clearly don't have anywhere near sufficient evidence about it, however we decide how and where the threshold for sufficient evidence is to be set.

At this point, one may object that there is an easy route to getting sufficient evidence about the nationality of the bronze medal winner at the Seoul Olympics, e.g. by looking on Wikipedia. This may lead one to question whether I have in fact shown that following DOXASTIC ATTITUDE will not involve believing this truth. If I'm trying to ensure conformity with DOXASTIC ATTITUDE with regards to the truth about the nationality of the bronze medal winner, wouldn't the best way to do that be to go on Wikipedia, rather than to suspend judgement? Doesn't DOXASTIC ATTITUDE therefore mean that I ought to waste my time looking this up on Wikipedia?

I don't think there is a problem here. The subsidiary norms which I've been thinking about are all norms that prescribe what one ought to believe. For this objection to succeed, we have to grant that there are also some subsidiary norms that prescribe one to perform certain actions. But it seems we can restrict the norms that a truth norm is supposed to explain solely to norms on belief.

Some have claimed that a truth norm should also prescribe some actions, e.g. that one ought to gather evidence (Horwich 2013, 29-31). But it seems acceptable to me if a truth norm only explains what one ought to believe in order to have justified beliefs, i.e. that a truth norm only explains when someone's attitude towards p counts as justified or unjustified given the evidence concerning $p$ they currently have. And for DOXASTIC ATTITUDE to explain that, it seems sufficient if the subsidiary norms one must follow as a means of conforming it are restricted to norms on belief. If there are any epistemic norms imploring us to gather evidence, they can be explained by other norms (norms on inquiry, perhaps).

Therefore, once we recognize that DOXASTIC ATTITUDE is only supposed to explain what one ought to believe in order to be justified, it then becomes clear that following DOXASTIC ATTITUDE will not involve looking up who was the bronze medal winner at the Seoul Olympics on Wikipedia. Rather, it will involve suspending judgement about it, because one does not have sufficient evidence.

This is just one example, but it seems we'll be able to say the same about all the canonical cases of truths which seem too trivial to believe, such as truths about phone numbers, truths about grains of sand, etc. It seems that I'm bound to not have sufficient evidence about such truths. Therefore, if for some reason I happen to have some doxastic attitude about such a truth, although DOXASTIC ATTITUDE will then entail that I ought to believe it, we can deal with it in the same way as the example above.

So although DOXASTIC ATTITUDE may prescribe believing some trivial truths, the means one should take to conform to DOXASTIC ATTITUDE will not involve believing the typical examples of trivial truths. This makes the fact that DOXASTIC ATTITUDE prescribes believing such truths unproblematic.

What about trivial truths which one both has an attitude about, and has sufficient evidence for? There seem to be two kinds of case in which one might both have some 
doxastic attitude and sufficient evidence about a trivial truth. But neither kind of case, I claim, is problematic for my account.

The first kind of case concerns people with very niche interests, e.g. people who go around gathering evidence and information about trivial matters (or at least matters the majority regards as trivial). In such cases, DOXASTIC ATTITUDE would prescribe that such people believe truths about their niche interests. I also admit that SUFFICIENT EVIDENCE-which I'm claiming one should follow as a means of conforming to DOXASTIC ATTITUDE-would prescribe believing such truths. But this looks unproblematic, because with such people it does look like they ought to believe these trivial truths, and would be unjustified if they did not so.

To illustrate, there is a website (www.moviebodycounts.com) which tracks the number of deaths depicted in films. The people who run this website probably do both believe that 836 deaths are depicted in Lord of the Rings: Return of the King, and have sufficient evidence for this (since they list the figure on their website). The best means for these people to conform to DOXASTIC ATTITUDE with regards to that proposition would, I grant, be to believe it. But this is unproblematic. If they disbelieved that proposition, or suspended judgement about it, they would look unjustified in doing so.

And although this is just one example, it looks like we'll be able to say the same about all cases in which people have both an attitude and sufficient evidence about a trivial truth because of their niche interests, such as in the cases of trainspotters, stamp collectors, manhole photographers, and hobbyists of other varieties.

The second kind of trivial truth which might still seem to be problematic for my account is the kind of trivial truth appealed to by Whiting, i.e. trivial truths which one has sufficient evidence about because they are logical consequences of other propositions which one has sufficient evidence for. Our earlier example was the proposition that either London is in England or Tolstoy wrote Great Expectations. Whiting claimed it was implausible that one ought to believe such propositions. Might these be trivial truths which both DOXASTIC ATTITUDE and SUFFICIENT EVIDENCE prescribe believing?

I grant that if one has some doxastic attitude towards such a proposition, then, according to my account, one ought to believe it. However, again, this is unproblematic, and we can illustrate why with the same example.

One either has some doxastic attitude-i.e. belief, disbelief, or suspended judgment-towards the proposition that London is in England or Tolstoy wrote Great Expectations or one has no attitude at all. In either case, my account is unproblematic.

Say one does have some doxastic attitude towards this proposition. In that case, DOXASTIC ATTITUDE will prescribe believing it. And since one also has sufficient evidence in support of this proposition, the means one should take to conform to DOXASTIC ATTITUDE-i.e. following SUFFICIENT EVIDENCE—will prescribe believing this proposition. But in this case, that doesn't seem implausible. Assuming one has some doxastic attitude about it, if one were instead to either disbelieve or suspend judgement about whether London is in England or Tolstoy wrote Great Expectations rather than believing it, then one would look unjustified in doing so.

On the other hand, say one does not have any doxastic attitude towards this proposition. In that case, DOXASTIC ATTITUDE won't prescribe believing this proposition in the first place, since DOXASTIC ATTITUDE makes no prescriptions with regards to propositions one doesn't have any doxastic attitude about. 
This is just one example of this second kind of trivial truth. But again it seems we'll be say exactly the same about every other trivial truth of this kind. For any trivial logical consequence of something I have sufficient evidence for, I either have some doxastic attitude towards it or I don't. If I don't, then DOXASTIC ATTITUDE doesn't prescribe believing it. If I do have some doxastic attitude towards this trivial logical consequence, then the means one should take to conform to DOXASTIC ATTITUDE-i.e. following SUFFICIENT EVIDENCE-will prescribe believing it. And this doesn't look implausible, because one would look unjustified if one disbelieved or suspended judgement about the trivial logical consequence in question.

Neither of these two kinds of trivial truth poses a problem for DOXASTIC ATTITUDE, despite being trivial truths that people can and do have sufficient evidence for. Perhaps there are some other cases of trivial truths that are problematic for DOXASTIC ATTITUDE, i.e. cases in which (a) one has some doxastic attitude about a trivial truth, p, (b) one has sufficient evidence that $\mathrm{p}$, and (c) one would not look unjustified in failing to believe that p. But it's hard to see what such cases would look like, and the burden of proof is on the critic of DOXASTIC ATTITUDE to provide them.

\section{Conclusion}

So should I believe all the truths? In defending DOXASTIC ATTITUDE as a response to the believing-all-the-truths problem, I've defended a qualified affirmative answer. One should believe all and only the truths one has some doxastic attitude about. That is the only reformulation of a truth norm that can avoid the implausible aspects of a prescription to believe all and only the truths, but without thereby becoming incapable of explaining justification.

In doing this, I hope I've also succeeded in suggesting a new direction for the philosophical literature on how to formulate a truth norm. The literature has often treated the formulation of a truth norm as if it were a logical exercise, successful if the resulting truth norm doesn't prescribe believing any problematic truths of one kind or another. This cannot be the whole story if a truth norm is going to do any explanatory work, and not be a mere curiosity. We also need to keep in mind whether the truth norm we end up defending can still explain justification.

Open Access This article is distributed under the terms of the Creative Commons Attribution 4.0 International License (http://creativecommons.org/licenses/by/4.0/), which permits unrestricted use, distribution, and reproduction in any medium, provided you give appropriate credit to the original author(s) and the source, provide a link to the Creative Commons license, and indicate if changes were made.

\section{References}

Andrić, V. (2017). Objective consequentialism and the rationales of "“Ought” implies "Can"”. Ratio, 30(1), $72-87$.

Audi, R. (1994). Dispositional beliefs and dispositions to believe. Noûs, 28(4), 419-434.

Boghossian, P. A. (2003). The normativity of content. Philosophical Issues, 13(1), 31-45.

Boghossian, P. A. (2005). Is meaning normative?. In C. Nimtz and A. Beckermann (Eds.), Philosophy-Science-Scientific Philosophy. Main Lectures and Colloquia of Gap.5, fifth international congress of the society for analytical philosophy, Bielefeld, 2003, (pp. 205-218). Paderborn: Mentis. 
Burnyeat, M. F. (1980). Can the sceptic live his scepticism?. In Explorations in ancient and modern philosophy, (Vol. 1, pp. 203-35). Cambridge: Cambridge University Press.

Bykvist, K., \& Hattiangadi, A. (2007). Does thought imply ought? Analysis, 67(296), 277-285.

Bykvist, K., \& Hattiangadi, A. (2013). Belief, truth, and blindspots. In T. Chan (Ed.), The aim of belief (pp. 100-122). Oxford: Oxford University Press.

Christensen, D. (2009). Disagreement as evidence: The epistemology of controversy. Philosophy Compass, $4(5), 756-767$.

Dennett, D. C., \& A. Steglich-Petersen. (2008). The philosophical lexicon. http://www.philosophicallexic on.com.

Driver, J. (2012). Consequentialism. Abingdon: Routledge.

Engel, P. (2004). Truth and the Aim of Belief. In D. Gillies (Ed.), Laws and models in science (pp. 77-97). London: King's College Publications.

Engel, P. (2013). Doxastic correctness. Aristotelian Society Supplementary, 87(1), 199-216.

Feldman, F. (1986). Doing the best we can: An essay in informal deontic logic. Dordrecht: D. Reidel Publishing Company.

Friedman, J. (2013). Suspended judgment. Philosophical Studies, 162(2), 165-181.

Gibbons, J. (2013). The norm of belief. Oxford: Oxford University Press.

Glüer, K., \& Wikforss, Å. M. (2013). Against belief normativity. In T. Chan (Ed.), The aim of belief (pp. 80-99). Oxford: Oxford University Press.

Hattiangadi, A. (2010). The love of truth. Studies in History and Philosophy of Science, 41(4), 422-432.

Horwich, P. (2013). Belief-truth norms. In T. Chan (Ed.), The aim of belief (pp. 17-31). Oxford: Oxford University Press.

Hume, D. (1748). An enquiry concerning human understanding. In L. A. Selby-Brigge (Ed.), Enquiries concerning human understanding and concerning the principles of morals, revised by $\mathrm{P}$. H. Nidditch. p. 1975. Oxford: Clarendon Press.

Jackson, F. (1991). Decision-theoretic consequentialism and the nearest and dearest objection. Ethics, 101(3), 461-482.

Littlejohn, C. (2012). Justification and the truth-connection. Cambridge: Cambridge University Press.

Littlejohn, C. (2013). The Russellian retreat. Proceedings of the Aristotelian Society, 113, 293-320.

McHugh, C. (2012). The truth norm of belief. Pacific Philosophical Quarterly, 93(1), 8-30.

McHugh, C. (2014). Fitting Belief. Proceedings of the Aristotelian Society, 114, 167-187.

Millar, A. (2004). Understanding people: Normativity and rationalizing explanation. Oxford: Oxford University Press.

Nelson, M. T. (2010). We have no positive epistemic duties. Mind, 119(473), 83-102.

Railton, P. (1984). Alienation, consequentialism, and the demands of morality. Philosophy \& Public Affairs, 13(2), 134-171.

Raleigh, T. (2013). Belief norms and blindspots. The Southern Journal of Philosophy, 51(2), 243-269.

Shah, N. (2003). How truth governs belief. The Philosophical Review, 112(4), 447-482.

Shah, N., \& Velleman, J. D. (2005). Doxastic deliberation. The Philosophical Review, 114(4), 497-534.

Sorensen, R. A. (1988). Blindspots. Oxford: Clarendon Press.

Sturgeon, S. (2010). Confidence and coarse-grained attitudes. In T. S. Gendler \& J. Hawthorne, (Eds.), Oxford studies in epistemology, (Vol. 3, pp. 126-149).

Sutton, J. (2005). Stick to what you know. Noûs, 39(3), 359-396.

Turri, J. (2010). On the relationship between propositional and doxastic justification. Philosophy and Phenomenological Research, 80(2), 312-326.

Wedgwood, R. (2002). The aim of belief. Philosophical Perspectives, 16, 267-297.

Wedgwood, R. (2008). Contextualism about justified belief. Philosophers' Imprint, 8(9), 1-20.

Wedgwood, R. (2013). The right thing to believe. In T. Chan (Ed.), The aim of belief (pp. 123-139). Oxford: Oxford University Press.

Whiting, D. (2010). Should I believe the truth? Dialectica, 64(2), 213-224.

Whiting, D. (2012). Does belief aim (only) at the truth? Pacific Philosophical Quarterly, 93(2), 279-300.

Whiting, D. (2013). Truth: The aim and norm of belief. Teorema: Revista Internacional de Filosofía, 32(3), 121-136.

Williamson, T. (Forthcoming). Justifications, excuses, and sceptical scenarios. In J. Dutant \& F. Dorsch (Eds.), The new evil demon problem Draft Version Cited. Oxford: Oxford University Press. 